University of Louisville

ThinkIR: The University of Louisville's Institutional Repository

Electronic Theses and Dissertations

1938

\title{
The little theatre movement in Louisville.
}

Fred J. Karem

University of Louisville

Follow this and additional works at: https://ir.library.louisville.edu/etd

Part of the Social History Commons, Theatre History Commons, and the United States History Commons

\section{Recommended Citation}

Karem, Fred J., "The little theatre movement in Louisville." (1938). Electronic Theses and Dissertations. Paper 1820.

https://doi.org/10.18297/etd/1820

This Master's Thesis is brought to you for free and open access by ThinkIR: The University of Louisville's Institutional Repository. It has been accepted for inclusion in Electronic Theses and Dissertations by an authorized administrator of ThinkIR: The University of Louisville's Institutional Repository. This title appears here courtesy of the author, who has retained all other copyrights. For more information, please contact thinkir@louisville.edu. 


\title{
URIVERSITY OF LOUISVILLE
}

THE IITHLE THEATRR YOVEMRNT IN LOUISVILIR

\author{
A Diusertation \\ Submitted to the Paculty \\ Of the Graduate School of Arts and Sciences \\ In Partial Ralfillment of the \\ Requirements for the Degree \\ of raster of urta
}

DRPARTMENT OP HATELISH

by

FRHD J. KARPM 
Tam of Student: Fred J. Karem

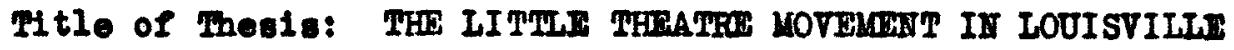

Tam of Director: D. W. Maurer

Approred by a reading committee composed of the following members:

Representative of the English Departuent:

nate: $(10 \mathrm{l} / 8 / 193)^{\circ}$ 
CRAPHER I

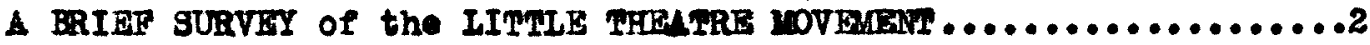
CHUPER II

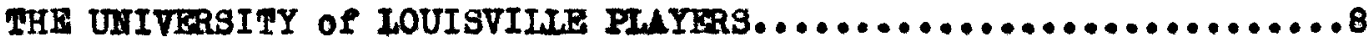
OHAPIER III

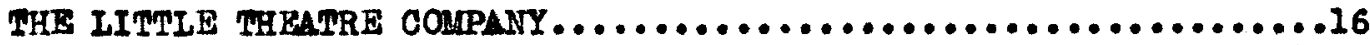
CHAPIER IV

THE ROSWITHA DRAMTIC CLUB of MAZARBHA COILBCE.............21 CHAPITR V

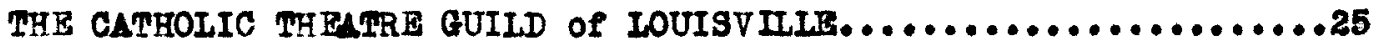
CHAPTER VI

MUNICIPAI $\triangle$ COTIVITY $\ldots \ldots \ldots \ldots \ldots \ldots \ldots \ldots \ldots \ldots \ldots \ldots \ldots \ldots \ldots \ldots \ldots \ldots \ldots \ldots \ldots \ldots \ldots \ldots \ldots \ldots$

CHAPTER YII

OHER GROBEg $\ldots \ldots \ldots \ldots \ldots \ldots \ldots \ldots \ldots \ldots \ldots \ldots \ldots \ldots \ldots \ldots \ldots \ldots \ldots \ldots \ldots \ldots \ldots \ldots \ldots \ldots \ldots \ldots . \ldots 3$

CHAPIER VIII

CONIRI BUTIOHS $\ldots \ldots \ldots \ldots \ldots \ldots \ldots \ldots \ldots \ldots \ldots \ldots \ldots \ldots \ldots \ldots \ldots \ldots \ldots \ldots \ldots \ldots \ldots \ldots \ldots \ldots \ldots$

CONGIUSION $\ldots \ldots \ldots \ldots \ldots \ldots \ldots \ldots \ldots \ldots \ldots \ldots \ldots \ldots \ldots \ldots \ldots \ldots \ldots \ldots \ldots \ldots \ldots \ldots \ldots \ldots \ldots \ldots \ldots \ldots . \ldots$

APPENDIOES

4. PHYS FRODUCED by the UIIVERSTY of IOUISVIIIE PLAYERS $\ldots \ldots . .40$

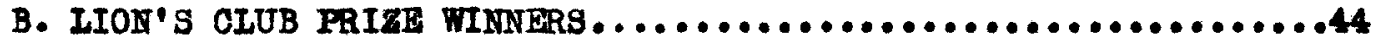

C. PIAYS FRODUCED by the ALUMNI PIAYERS $\ldots \ldots \ldots \ldots \ldots \ldots \ldots \ldots \ldots \ldots \ldots \ldots .4$

D. IIAYS FRODUCED by the IITTLE THEATRE COAPANY.............46

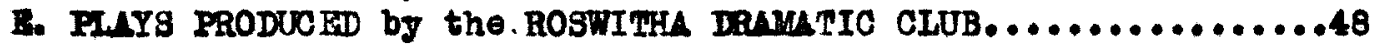

F. FLAYS FRODUCED by the CATHOLIC THEATR GUIID.............50

G. PUAY FRODUCED by the IOUISVIILE CIVIC THEATRR............52

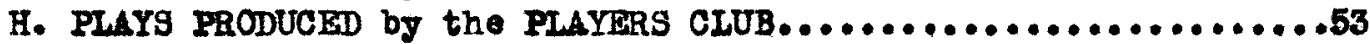

I. AUPHORS OF PIAYS PRODUCHD by IOUISVILIE'S LITTLE THEATRES . . .54

BIBLIOGRAPHI $\ldots \ldots \ldots \ldots \ldots \ldots \ldots \ldots \ldots \ldots \ldots \ldots \ldots \ldots \ldots \ldots \ldots \ldots \ldots \ldots \ldots \ldots \ldots \ldots \ldots \ldots \ldots 61$ 


\section{GHAPIER I}

a BRIEP SURVEY OF THE LITTLE THEATRE MOOVEATIT 
THB LITLLE THRATRE NOVEAENT IN LOUISVIIIE

$\mathbf{I}$

4 Brief Burrey of the IIttle Theatre Horement

lature The origin of the anoient and of the modern drame is denoand Parpope oratio in the elnest sonse of the word, ince it is found In e fundamental noed of hwoun nature, public worehip. Among the cerly Grock the firet pleye wore religlous functione performed by the people; 10, too, the early Ohristians dremetized the Bater. sequence of the lase. 1 Gradualiy in both the pagan and the Ohristian drame, the religious motive and content gare place to secular motires and seoular oontent, though indead, the second large phase we educative without belng didactic. The Oreek dramas of Lesohylus, Sophocles, and Bartpides were not only great art, but were also morel and patriotio theses addreseed to the peoplo. In like manner the Noralities and oven the great plays of Shakespeare were designed to instruct and to elerate the people. It was the "grounding" who fixed the place of Shakeapeare. The decline of the ancient and of the modern drama began when the theatre became a place of amusement exploited for 1 te commerciel relue. ${ }^{2}$

The 11ttle theatre morement of the twentieth oentury is only one of the meng movements wich fom time to time during these periods of deoline have striven to retarn art to the people and to combat commercial1setion, for this movement is "the arch foo of commercialism. $n^{3}$ Ite demooratio character is evident in its personnel, for the term "little theatre" is not deseriptive; it might be oalled more correctly the amatour moverent In the theatre in 80 far as it is the reant of the growing activities of

1. Hughea, 41 cm, The Stary of the Theatre, p. 95 .

2. Oheney, Sheldon, the Thentre, pp. 289-201.

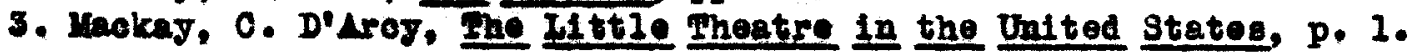


amateura in the field of dramatic production. It is differentiated from the professional theatre in thise its motivating force is onltural and artistic achlerement, not peounlary gain. In the soneo that it is nonprofeseional and non-luorative, the 1ittle theatre had its counterpart in the wagon-stage of the medieval guilde.

Origin Resentially, however, the morement is comparatively new, In France harins originated in Frence in 1887 with the establishment 1887

of a non-profeseional theetre by Andre Antoine. ${ }^{2}$ So imbued With the Idea of a little theatre wae intolne that he eave up a Inoratire poultion to devote himself entirely to the renture. Though his ploneering work falled to repay him finanolally, it brought him ultimately an honor prized by Frenchen above all others, memberahip in the Leglon of Honor. "He won his fame," Kenneth Mactowan says, "through the opening he gare to the modern realistio playwight. ${ }^{2}$

The 11ttle theatre 1dea spread through France eren during the Iife time of Antoine. The Theatre d'Art was founded in 1891; Theatre de 1'Oeurre in 1893; Theatre des Arts in 1907; and, the most notable of all French 11ttle theatres, the Theatre au Vleux Colombier, in 1918.8

Erapopean The founding of the Noscow Art Theatre by Oonatentin StanDorelopment 1slaraki in 1898 was the first frult of Antoine's ideal outaide of Franoe. Under the leaderohip of Stantslavekl this group made admirable progress, succeeding finanoially as well as artistically.

1. Hughes, Q1enn, op. clt., p. 257.

2. Footliente 1 crose Ameriog, p. 28.

3. Hughes, GIonn, Op. O1t., pp. 259-260.

4. Ibld.. Pp. $26-366$. 
These two ardent theatre lovers, Antoine and Stanislavsk1, pered the way for a new idee in the theatre. Irom their ploneer efforts the movement expended throughout Burop - Germang'g little theatre morement has given the theatre a geniue, Lax Relnhardt, who began his career as an arateur with his famous Kleines Theatre.' Bngland, too, felt the morement and responded in 1891 with Orein's Independent Theatre, which presented Bernard Shew to the theatre. 2 To Amorican the Lbbey Theatre of Dublin 1s, perhaps, best known of all forelgn little theatre groups, because the players have toured the states a mumer of times. Founded by Iady Gregory and Wiliem Butler Yeats and financed by Mies A. B. P. Horniman, the Abbey Theatre became a national theatre famous in the vorld of drama." Probably erery Buropean Capital had its quota of little theatre groups, presenting all pheses of dramatic productions, experimenting and perfocting, until finally the little theatre has taken its assured place in the erolution of the drema.

Ittle Theatre in the U.S.A.
Although the 11ttle thestre morement in the United States bogan with the visit of the Lbbey Plajers in 1911 the Thallan Assoolation, an amateur group, produced plays in wilmington, M.C., as early as 1800. Urs. Anna Cora Mowatt produced plays in the back parlor of her home in Brooklyn in the early forties and inraded Broalway With a play called Fachlons in 1845. Kenneth Motowan, howrer, oredits Brigham Young with the foundation of the first little theatre in the United States, the Desert Dramat10 Association, which produoed ita first play in 1853. 5 Ton yeare later the group built a substantial playhouse.

1. Hachowan, Kenneth, op. O1t ., p. 24.

2. Nackes, O. DiAroy, Op. c1t., p. 7.

8. Mactowan, Konneth, op. 1t., pp. 38-35.

4. Ibid., pp. 25-40.

5. Ibid., pp. $42-45$. 
Not unt1l 1911 when the Abbey Plagers of Dablin oame to America for an extended tour did the Onited States become 11ttle theatre consclous. ${ }^{2}$ The Warhington Square Players ${ }^{2}$ and the Provincetom Plagerg were the results of this consclousnese. They were unquestionably the most stable forerunners of the morement in this country.

The derelopnent of the Provincetown Players was parallel to that of the Wanington Square Players. They launched upon their successful royege in little theatre hietory at Prorinoetown on Cepe Cod during the summer of 1915. The Players converted an sbandoned fioh house into a theatre and were so succesaful that they were soon operating a theatre in Provinoetown in the sumer and in Few York during the winter.

Two other 1ittle thestres growing out of an entirely different enviroment came into actual existence about the same time as the Washington and Provinoetown groups. These organizations were the Hull House Players of Ohioago and the Nelghborhood Playhouse of New York. Both grew out of dramatic activity in settlement houses and developed into highly officient dramatic organizations.

Dramatic aotivity in religious organizations, or clubs with arowed donominational affiliation, is older than the little theatre novement 1tself. Recently, however, this ectivity hes been crystallized into definite 11ttle theatres. The Cathollc Theatre Conference, for example, which was organized in Chicago in 1937 has for its objective the unifloation of Catho110 dramatio cluba into a national Cathollc 11ttle thestre.5

\footnotetext{
1. Huches, Glem, op. olt., p. 360 .

2. Mnokeg, C. Dilicy, op. cit., pp. 27-38.

3. Ibid.., pp. 46-5s.

4. Hactowan, Kenneth, op. olt., pp. 47-50.

5. Bullotin Oathol10 Theatre Conference, Vol. 1, p. 1 .
} 
Lemin dramatic activity in various unirersities is another phase in the derelopment of the little theatre movement in the United States. Under the leaderonip of feorge Plerce Baker, one of the moat important unirersity 11ttle theatres wes founded at Harrard. The "47n Torkhop has become significent in amateur dramatics, beeause Bakor's forte being the teaching of plagerighting, the Hervard Woricenop has produced coninent playwights. Minelig the first sohool of ecting, directing, and general dramatio production wa inctituted at the Carnogie Inotitute? of Teehnolosg under the supervision of Thomes Wood Sterene. 2

With the deoline of the "road" the importance of the i1ttle theatre has increased until today it is an integral part of our drama, and mast be considered by future hietorians of the drams. It is the only oxietIng means of bringing the theatre to the regions west of Broadray.

The l1ttle theatre in the United States has dereloped along the followlag four lines the 11ttle theatre founded by those imbued with a lore of drama, the little theatre in settlement centers, the little theatre in institutions of higher learning, and the little theatre in its religlous aspect.

It Is along these four lines, also, that we wish to conduct the present theais, the little theatre in Louloville. What progress has the 11ttle theatre movement made in Loulsville i Phis will be the question, the problem, with wich this work wil be concerned in subsequent chapters. The atudy of this progress will includes problems of organization, production problem, and problems connected with public relations.

1. Euches, G1emn, op. c1t., p. 867.

2. Hnolown, Kenneth, op. c1t., pp. 47-50. 
Ls the thesis deals with a field that has not been explored, the material he been collected from original sourees. The anthor has been connected with two of the little theatres which will be otudied, In the oapacity of director for nine years. He has beon an active member of the other two for over ten years. He has interviewed mang members of each organizatIon; ${ }^{1}$ he has examined the avalleble reoorde; and he has consulted newepaper stories concerning Ioulsville' 1ittle theatres. The four major productue organization. constituting Louisville' little theatro to be considered herein aresthe Unireraity of Louigville Players, the IIttle Theatre Compeng, the Cathollo Theatre Guild of Louisville, and the Roewithe Playera of Tazaroth College. 
CHNPTER II

THE UNIVERSITY OF IOUISVIIIE PIAYERS 
II

The Univereity of Louleville Players

Foundation Drematic activities in universities oan be traoed almost to the beginning of the institutions thenselves. When these activities were linked with the study of the theatre, the unirersity product took on definite little theatre oharacteristlos. This prooese Pirst came to 11ght at Harvard in $1908,{ }^{1}$ monoe it rapidy opread throughout the country. Hotable among the early leader of the little theatre movement in unirersities were Carnegie Institute of Technology, Iown, Northreatern, North Carolina, and our own University of Loulaville.

Dr. John I. Patterson, deen of the College of Arts, Introduced drametic aotivi by the University of Loular1l1e in 1911 by organizing the Dramatio Club, the name of which was ohenged to the University of Ioulavilie Players in 1914 men Mr. Boyd Martin became director.

Derelopment The College of Ilberal Arts of the Univeraity of Loulsville of Plant was located in an old maneion on Broadway between Firat and Second Streets when the Univeraity of Louievilie Plagers were first orgenized. The Plager were alloted amall hall in which they constructed a $12 \times 25$ foot stage, using ohurch pewe as seats in the "house." In this minute theatre known as the Dorkehop, the Players worked, played, and progressed for eleren seasons.

When the Uni varsity of Loulavilie College of Ilberal irta mored to the present Campus at Third and Shipp Streets, an old Ghapel was glion to the Players for their nem home. This Chapel was reconntructed, 
ohanged into a complete modern thestre, and ohriotened "The Playhouse," The formal dedication took place in November, 1925 with a production of Pernec Molner's the Swen.

The atmosphere of the theatre in the Playhouse 18 ereatly onhaneed by the famous collection of yacauley plotures which adorn the walls. These plotures were presented to the University of Ioulsille Players by Mrs. John T. Hacauley in order that they might remain permanontly in Loulsorlie in suitable surroundinge, and surely no more sultable arroundings oould be found for the plotures of men and women whose 11 res were deroted to the stage and the drama than this ploturesque little Playhouse which seems oteeped in the rery splrit of the theatre.

O17ic

Paterprices

Brar mindful of the faot that they are a part of a municipal Inetitution, the Players have always relconed overy opportunIty to join in oivic affalrs. It was during the 1918-1919 season that the Unirersity of Louleville Plajers produced Sir James Barrie' the sdmirable Crichton at Meavley'. Theatre for the benefit of the Permanent Blind Relief War Fund. In appreclation of their aseistanos, the executive comittee of the Fund sent the Players an emblen in the form of a pin, which has ainoe been adopted as the offloial emblem of the organization. In comemoration of ite origin 1t has become the custom for the Players to award it to members doing distinctive work.

Widening the scope of their activities the Plagers embarked upon a new little theatre venture during 1925 when they conducted the Ilttle Country Thestre at the Stete Pais. ${ }^{2}$ The 11ttle theetre was conducted in a tent, the etage being a plain wooden platform. S1x ono-act plaga were

1. Iouigr1110 Times, November 14, 1925.

2. Cour1er-Jourzal, September 11, 1923. 
presented, one each hour beginning at two 0 olock and continuing through unt1l veven o'0look. Over three thousand people witnessed this nen experiment which was one of the ploneer efforts of its kind.l

The Players' next exoursion beyond the reeime of their own Immediate phere was the presentation of the old English play, Oammer Gurton's Meedie, at the Convention of the Modern Ianguage Aseociation wioh met in Louistille in Jenuary of $1928 .^{2}$ This pley wich is one of the first written in the Ingliah language, was a happy choloe for such a meeting and proved conolusively that the Playors strive to maintain their purpose for existence, Mo provide educetionsl festures in iramatio production." That the Pleyers heve not forgotten their purpose with the paseage of the years 1s proved by their cooperation with the Woman's Club of LoulsTlle in 1985 to bring Barrett H. Olark, one of the Country's foremost dramatic authorities, to Ioulaville, where he delivered a public address at the Eomn's Club Auditorium. 3

Pub11c Reoognition

A work vell done is a reward in itself; yot it is pleasing for any organization to know that the work it is doing is appreclated by others. On June 8, 1925 the LIon's Club of Loulsollie in recogntition of the value of the Univeralty of Loulaville Players to the community, eatablishod a prise to be awerded to the student dolne the best work in dramatica during each season. I fund of $\$ 1,000$. Was set aside for this purpose, and its inoome was desicated as the Lion's Club prize."

\footnotetext{
1. The alx plays presented weres Helchbors, by som Calei Orertones, by Alice Geratenberg; The Dear Departed, by Stanley Houghton; Teeth of the Gift Horne, by Uargaret Cameron; Op Of Me Thumb, by Frederick Penn; and, Fie Eedolet, by LIfred Sutro.

2. Alumil Bulletin, February 1928.

3. Cour1er-Journal, Uay 11, 1955.

4. Sec Lppendix for llat of Lion' Club prise winners.
} 
Local recognition wae soon followed by national recognition. As early as Jemuary, 1926, The Drama, a magazine deroted to theatrioals, carried an article about the Plaghouse and the University of Loulsville Players. The Chrietian Solenee Yonitor in its losue of Lpril 13, 1926 printed a ploture from Ine gman, and featured a story concerning the new 11ttle theatre. Drema followed its January atory with another in the lay 1sene.

The Unireralty of Louigville Players increased their national prominenoe with the production of Romeo and Juliet during the 1926-1927 ceason. Drema, Theatre Arta Monthly, and Theatre each carried a sory of the produotion which was one of the most beautiful, mateur or professional, -rer given in Iouloville. Plotures from $\leqslant$ Gerden of vemories appeared in the June, 1984, 1s sue of Theatre Arts Yonthly and were followed by a news story in the July 1ssue of the ame jear.

Organization the Unifersity of Ioulaville Players is an organization within and Punotion the Onireraity and under its function, but mutters of adminieof

Offioers tration and the management of intermal affalre hare alwaye been left, to a great extent, in the hands of the director and to suoh offlcers as have been deoned necossary. In the beginning the Univeraity oharged the director Wth the organization of the olub, and It was he who derised the system of goverment now in existence.

The usual president, vice-president, and secretary, as well as - house manager and business manager, are elooted by the members. Such teohnioal officers as stage maneger, property mistress, and eleotrician are appointed by the director. The group's one deviation from the commonplace in the choosing of officers is the selection of an appointed treasurer who is always a member of the faculty or administrative ataff of the Onivereity. The tities of the officers are self-explanatory of the duties entailed. 
The

Three

Departments the three major departments of gorernment, stage, house, and

business. The stage department is under the direot supervision

of the etage manager who is responsible for the efficient handing of all

auch technloalities an properties, prompting, rohearsal sohodule, eleotrioal

effecte, wardrobe, oound offects, and in general all backstage work.

The comfort of the Players' andienos is dependent upon the

house manager who must see that the auditorium is cleaned and properig heated, that the ushers are well trained and on time at productions, and that the doormen is selocted and at hic station promptly. He must attend overy performance, handle all complaints, and adjust any differences that may arise. Opon the shoulders of the business manger rest the responsibilities of conducting the season subsoription campaign, the salo of tickote for each play, pablicity and advertialng, the allocation of reservations, and the care of the box offloe.

Mcaberahip Any rull time student of the University tho is in good standing 1s eligible for aotire membermip in the Players. All students of the College of Iiberal Arts are required as part of the student actirity to purchese tiokets to productions. Broadiy opeaklng, therefore, the members of the student body of the College of Ilberel Arts are members of the Playora. The memberanip of the Olub has been dirided, then, into actire and associate nembers. Lotire members are those who have been avarded the Players' emblem, 1 mile assostate members are considered as apprentices in the organization. The highest honor possible to achiove in the Pleyers is the winning of the Ilon's Club prise, mion is amerded by the direotor to the student doing the moet outstanding work in dramatice during each sesson. 2 
Production Dramatic produetion at the Univeraity of Loulspille began Toohnl que

Trandition before the University could boast of a atage of any kind. Sohool rooms wore utilized for rohearsals, and the one mejor production each season was prosented at Kaoauley's Theatre. Then the Dramatio Club becane the UnIroraity of Loulerille Players, ${ }^{1}$ the Workehop Wea used for all purposes except the ennual production at lacauley's Theatre. Then the Unireralty of Loularilie Pleyers moved from the Workshop into their present home, the conversion of the old Chapel into a theatre was made posalble by the addition of the stage and dressing roans. Very 11ttle of the equipment in the Forkahop could be ut1lized at the Playhouse becaune of the difference in the ize of the stage. After working on the almost miniature scenery used at the Workahop, the bullding of what might be termed full size soonery was an undertaking and readjustment for the stage orew; yet every atick of scenery used for the firat production at the Plaghouse was designed, built, and painted by the studente.

The Playhouse was completely renorated during the 1985-1986 808son, when it became the object of a W. P. A. projeot. At this time a warohouse was constructed under the stage; the seats, floora, and walla were painted; and a thermostatic heating systen was installed.

Soenery Because of the nature of the organisation, the memberahip of the Player is constantly changing, making it necesary for the diroctor continually to teach the rudiments of stagecraft to nem members. Denplte this change in membershlp the Players have continued to advance in the art of building sets until at the present time theg hare used praotionlig orery kind of setting in major productions exoept the conetructiviotic with whioh they have experimented only in Saturday afternoon productions. ${ }^{2}$

1. See above, p. 8 .

2. The saturday afternoon productions are handled entirely by atudents and are for experimental purposes. Ueually the plays are original. 
The productions have been chlefly in the conventional box set after the modified naturalistic sohool which substitutes solid scenerg for the painted scenery of the old school. The modified naturalistio school tends even more to reallam by having solid doore and windora. Nimost wery play produced calls for at least one such set.

The firat radical departure from the naturallatic setting was In the production of Bomeo and Juliet, for which a combination of the unit, naturalietio, and sculptured stage was used. The unit type of setting is so naned because the sots are oomposed of units which mag be rearranged to seoure entirely different effects. The sculptured setting is made up of terraces, stops, and platerms.

The Players' production of $\underline{Y}$ Lady'e Dress required numeroue quick changes which were effected by the use of a wagon stage. Two catormounted platforms wore built just wide onough to fit exactig into the wide arch in the shallow maln set. The ecenery was set on each platform and rolled into plaoe as needed, making it posalble for the stage orew to change the scenery on one wagon while a scene was being played on the other one. St111 another type of set used by the Players was the "Jacknife" stage which was used to fade from one period to another. This effect was secured by again using two platforms on castors; but instead of rolling strulght on, the platforms were bolted on each side of the proscentum aroh and wore made to swing in a semiolrcle until the platform come to rest with 1ts front side againgt the one foot rise wion had been bullt at the foot11ghts. 
Other

Production

Iteme

In order to present a balenced production the Players insist upon authentic settinge accompenied by the use of appropriate propertles and carefully planned lighting effecta. The properties are uenally borrowed although it is sometimes necessarg to construot them as they cannot be secured otherwise..$^{2}$ The urtchboard at the Playhouse is equipped to take oare of practically any lighting situations that arise In production, each olroult being equipped with a dimer and the auxiliary lighting equipment belng of the same oallbre as the switchboard."

Since the members of the Players are students and acting must be taught to them, the willingmess to work is of prime importanoe in casting. Plays are generaliy in reheareal four weoke before the technical work is coordinated with the acting at the dress rehearsal. The Playere have made onviable progreas in production, but of equal importance is the friendahip and good fellowsip which result from working together for a cormon cause.

Audienoe The audienos of the Untrersity of Loularille Plagere is made up of the general pablio and students. since the Plagers are at the same time a ilttle theatre and a self-oupporting organisation their choice of plays is somornat limited as they mast both conform to the standard of a little theatre and appeal to the public taste. The Plagers have Inoluded in their ropertolre classic plays, Broadway hits, and original produotions.

1. Framples of such properties were the two-tier chandelier used in Peole and Prancheses, and the lamp used in Romeo and Juliet.

2. The mitohboard cost the Players approximately 6,000 .

3. See above, p. 12 . 
CHAPIER III

THE IITILE THEATRE COMPANY 


\section{III}

The Little Theatre Company

Lfter the risit of the $\Delta$ bbeg Players during 1911, the 11ttle theatre morement became manlfest in the United Staten, and ande Ita appearance in sereral cities simultaneously. In Iouleville the morement began with the formation of the old Dramatlo Club, whose existence, although short 1ived, Justified iteelf in that it was the forerunner of the Plagers Club, Which later combined with the Alumi Players to form the present Iittle Theatro Company.

Plagere $\Delta$ group of theatre-minded people under the leaderahip of Fathen Club Bloom met Jaroh 6, 1917, and, determined thet Loulsville should have its little theatre, organlzed the Players Club. The Club limited its activities during the first fire jears of its existence to the production of orleinal one-aot play, ${ }^{1}$ but by December, 1922 the Playere mere ready to produse their firat fall length play. ${ }^{2}$ From that time theg presented regular seasons of full length plays, but they did not relinguish their aotivity in the field of one-sot plays; these were used to supplement their major productions. 3

By the beginning of the 1931-1932 season the Players Club rea11sed that its policy of haring a dfferent director for each production was not giving full satiafaction, and it decided to ask Mr. Boyd Yartin to take orer the directorship of the organisation. It was during this season that

1. Nmong such production weres The Female of the Speoles, by Nathan Blocm; Vire I'Imperur, by Judge W1Illam Hiold; and Fane Bublo' ' Puppett, by Grace Doreas Buthenburg.

2. Diplomes was presented at the Woman' Club Auditorium, December 13, 1922.

5. The major productione included, Ion and I, by Philip Barry; John Permson, by St. John Brvine; The Dhlteheaded Bor, by Ionox Robinson; Swemp Blrd, by Calo Young Rices and The Elerator Door, by Credo Harris. 
the members of the Players Club and those of the Alumi Plagers became consclous of the fact that both organizations were working for the same cause and interesting the same people.

Alumi

Player.

Through the efforts of former members of the Univeralty of Lonieville Plagers, the Alumi Pleyers were organized in the fall of 1927 under the sponsorehip of Dr. John I. Patterson and Ur. Boyd Martin. The experience whioh the members of the new organization had gained in their undergraduate days did mach to insure the sucoese of an ambitious sesson; 2 noreover they filled a neoseary place in Ioulspille': I1ttle theatre history: novertheless by the end of the 1951-1932 season, they wore ready for the next logical step in thelp derelopnent; that is, amalgamation with the Players Club.

Consolidation The union of the Alumi Players and the Plogers Club was -ffected during the ewwer of 1932 by an orcanigation comolttee composed of members of both Clubs. Through an agreement betwoen the Alumnt Plagers and the University of Loulaville Players the new IIttle Theatre Company was permitted the use of the Playhouse for 1 te produotlone, the firgt of these, $\leqslant$ Damsel in Dietreas, was presented November 10 , 1932. It was a gala occasion with Dr. Raymond 4. Kent, president of the Onlvereity of Iouierille, delivering the address of welcome, and the andienoe receiving with warmth and enthusiasm this new little theetre.8

1. The committee for the orgenization of the Alumi Players was headed by Buth Wison who in her undergraduate days had been one of the most active of the Univeraity of Iouleville Players. Serving on this ocmitte were George Patterson, Bdmand Bottomley, and Hugh Sutton, each of whom had been prealdent of the Uni rersity of Loule ville Pleyers.

2. The Plagers produced five plays during their first season.

3. Courier-Journal, November 11, 1932. 
By taking the best from each of its parent organizations and arolding thelr mlotakes the Ilttio Theatre Company has developed into the most mature of Ioulsvillo's little theatres. In 1ts efforts to realize the expressed mission of all such organlzations - keeplng al1ve the spoken drams as excmplified on the stage - the I1ttle Theatre 18 striving to alleviate the thirst of the individual to whom art and drame are symonymous.

Lemberinip When the Pleyors Club and the Alumi Players merged into the Ittle Theatre Company, It was neceseary to ohange the rules on membership as the one organization atressed social prominence in its membere while the other required it players to be Uni versity sraduates. The new I1ttle Thestre Company deolded that any Interested Louidrillian willing to parchace a souson ticket should be entitled to membermip; howerer members are divided into active and associate, active members being those who aotually take part in the work of the Company and assoclate members being those who are primarily interested in seeing the results of production.

During the 1935-1936 veason the Iittle Theatro Compang Inaugurated the custom of presenting an honorary award to the player giving the best performenoe of the season. This player was chosen by secret ballot, each member voting for the member whom he considered most deserving of the award. ${ }^{1}$

Goverment The administrative body of the Ilttle Theatre Company which is called the Board of Governors it composed of preaident, ricepresident, tresaurar, and nine members at large all of whom are eleoted by a rote of the sctive members. The executive eecretary whose enties inolude the care of the box offlce, reservations, and correspondence is appointed by the

1. Gizabeth 71 son was the reolplent of the award in 1986 for her performance in Yrs. Yoonlieht. Ph1l1p Holl enbaoh was evarded the honor in 1937 for his portrayal of Samul Pepgs in And So to Bed. The reolplent of the eward in 1938 was Homer Burton Blackrell for his role in The Circle. 
Board and pald for her servicen. The Ilttle Thestre also has atage manager who during the past season has been given membership on the Board of Corernora, and a cheirman of ushere who is responeible for ushers, dooman, and arrangements for the coffee wagon. ${ }^{2}$

Comittees The task of recrulting old members and of securing new ones is handled by the membership comittee, which is appointed by the president. In the early days of 1ts existence the Itttle Theatro also used a playreading and a casting comnittee, however as the Board found that the duties of the playreading committee derolved upon it, and as the casting of plays by comittees prored cumbersome and ineffectire, both comittees were discontinued.

Produotion The Iittle Theatre Company is the most fortunate of Loulaville's Probleme

11ttle theatres in that it has fewer production problems than any other. When the Compeny wag organized, the agreement between the University of Loulsville Playere and the Llumi Pleyers conoerning the use of the Playhouse was taken over by the new organization; thus all of the equipment and fecilities of the University of Loulaville Players were placed at the disposel of the Compang.

Is a result the Iittle Theatre found itself in a fully equipped, permanent home with only one real production problem - that of building soenory In a limited time. Since both organizations usueliy present fire plays per sesson there are ocossions when two productions are being prepered at the sane time, and scenery for both plays must be bullt simultaneously. The atege oren must exert, therefore, a maximum of effort in a minimun of time.

1. In the foyer a emall gayly decorated wagon called "The Coffee Wagon" in used for serving coffee and cakes to the audionoe betwean the second and third acts of Little Theatre Company productions. 
Further reduction of problems is due to the feot that the mejority of the members of the Ittle Theatre, having acquired their training with the Players Club, Alumi Players, and the Univeraity of Louiaville Plagers, are akilled in the art of play production and especially adepted to handle efficiently the authentio design and beokground required for the ordinary box set after the modified naturaliatio sohool that is required for most of their productions.

Playe ginoe in recent years no road shows hare visited the clty, the I1ttle Thentre Compeny has been the link botween the publlo and Brosdway. Le a result, the Company has endearored to present the type of plays mich will find a ready andlence and at the same time to keep the city familiar with the productions in other large metropolitan centers. The Company must be self-supporting, and at the present time that means that it is Imposible to take many chances with experiments in the theatre. In most Instances only the tried and true box office shows can be produced, as the public from which the organization drawe its associate meabera must be pleased, and in order to please them the Ifttle Thentre must act as IoulsT111e' subutttute for Broadway. 
CHAPIER IV

IHE ROSTITHA DRNATIC CLUB OF NUZARETH COLLEGB 
The Rouwitha Dramatio Club of Nazareth College

History It may surprise one who is unfamiliar with the ilfe of roliglous women to find that dramation have beon popular In convents since their establishment. Is early as the ninth century we find Hroowithe, a German nun, writing plags in Latin to be presented by the nuns of her community during their perlod of reoreation. ${ }^{1}$ Here in Loulaville, Nezareth College, the only senior college in Kentucky exclusively for wonen, has followed the age-old tradition.

Dramatic activity began at the College almost simultaneouly with its founding in 1920. Durlang 1923 the dramatlo activity was organized Into a little theatre oalled the Roswithe Dramatic Club, 2 mich presents two public programs each season, one in the fall and one in the spring. The club supplements these public programs by promoting the plays presented by various olsases at asaemblies and by the production of original one-act plays at its monthly meotings.

Yembershlp Being a part of a College for women, the Roswitha Dramatic Club's membership is open only to students of the College. There have been many instances when a mele memberahlp would have been beneficial to the Club, and the Ides wes discussed at the beginning of the orcantzation; but the girls have courageousiy maintained the tradition of IImlting the school's actiritles to 1 ts own students. Membership is open to ang student of the College who carries twelve or more hours of college work and 18 in good standing in her classes. Candidates for membership must "tryout" and be roted upon at the beginning of each seeson. 3

1. Hastinge, Charles, The Theatre, p. 96.

2. The Club was named in honor tho the German nun, Hroswi the.

8. Constitution of Roswitha Dramatio Club, Articles III and IV. 
Organiation When the Club wa organized, the faoulty deomed it wise to allow the students to manage the details of organization for themselves; consequently the Roowithe Dramstio Club was allowed to take root and grow in the soll of its own initative. The governing board of the Club is composed of president, Fice-president, secretary, treseurer, and two edvisory members, a moderator who is always a member of the faculty and the director. 111 officers who flll the technical positions are appointed for each production thus stimulating interest and sotivity among the member 8 .

Production By the nature of the organization the produation problems of Problems

the Club are greatly inoreased. The construction of senery 18 at best a somewhat difficult task for girls; but when they have no little thestre of their own in which to work, the difficulty is inoreesed. Unt1l the sumer of 1935 the Olub used Presentation Academg's Auditorium as its workshopt however during that summer the Auditorium burned and has not been rebuilt; hence the Roswithans are without a permanent home in wich to oarry on their activities.

When the Presentation Auditorium burned, the Club lost all the soenery and stage equipment which the members had built and purchesed since their organization. The scenery required for Columbie Auditorium which the clab used for its major productions, wa much larger than that used at Preaentation, moreover the members could not repaint or change the coenery belonging to Columbia. 
Lack of soenery and difficulty of contruction led the members of the Roswitha Dramatic Club to develop efficiency and artistry in the use of drapes to augment the arailable soenery. One background was used for many productions, the different effects being secured by the use of flate ${ }^{1}$ and silhouette plece in conjunotion with proper 11ghting. ${ }^{2}$ gtage lighting 1s a somowhat lllusive art but spurred on by the lack of facilitios in soonery, the Roswithans came to realize the importanoe of lighting and developed a cormendable akill in bringine out the potentlallties of a setting by means of effective lighting.

The major production problem which faces the club is the portrayal of male roles by young ladies. This necessitates not only the interprotation of the character intended to be simulated but also the assumption of the characterietics and mannerisms of a man."

Plays Because of these particular production handicaps the actirity of the Roswithe Dramatio Club has been restricted, at least in public productions, to costume plays or playe with all female casts. The Club has produced at least one classic play each season, but extreme care must be taken in choosing these pleys as the publio taste must be considered. 5

\footnotetext{
1. The members designed, built, and painted an unique setting for their production of Pomenier Walk, which was presented in the1r workshop. Six i1ttle houses were very effectively depleted on a stage that measured $12 \times 20$.

2. The production of the Rivale required a scene using trees which were cut from cardboard and used in silhouette.

3. In gailin Through an innovation in staging technique was effeoted by Ingemalty of arrangement and lighting. During the cut-back the College Glee Club was inserted into the action. Small pleces of cheesecloth thrown orer the ohoulder of the girle gave the effect of the same costume for each one. Coupled with the soft lighting and the singing of the theme song the innovation produced a very beautiful and unusual effect.

4. This includes the lengthening of the stride in walking and the lowering of the voloe.

5. The Club has produced such plays a The Bivels, She Stoops to Conquer. Iwelfth Iight, Ilttle Women, and Bveryman. See Appondix for a complete list of plays.
} 
During the formative years of the organication the moderator and director chose the pleys to be produced, but now the problem of pley selection is 1.

Costume The production of classio plays necessitates, of course, the Department use of costumes. It first the Olub rented such costume as were needed, but reallzing that this meant an outlay of money for which there could be no permanent return, the members decided to make their own costumes. The wardrobe has enown with the number of productions until now the club can costume almost every type of play. Indeed authentic and artistic costuming has become one of the outstanding achlerements of the Roswithe Dramatic Club. Lohievements The growth of the costume department is perhape the most outstanding achierement of the Roswithans, but it is not the only? one. The Club is self-supporting, and considering the type of play produced and the limited memberahip this is no mean feat. The Club has, moreover, from time to time de oustantial donations to the mother institution. 
OHAPIER $\mathbf{V}$

THE CATHOLIO THRAPRE GUILD OF IOUISVILHE 


\section{V \\ The Catholic Theatre Guild of Loulsville}

Inception Drame and the Catholic Church have walked hand in hand many times during the course of history. The Church was directly reaponsible for the revital of drama in the Middle Ages, when it was sorely In need of a friend. In our present era, there are indications that the Churoh and the drama w11l again be linked through the numerous Catholio 11ttle theatres such as the Catholic Theatre Guild of Louistille.'

In the early part of Doomber, 1981, the Alumnae of Nasareth College produced a play for the purpose of alding the Alumne Association in a drive for funds. At the terminetion of the production the ides of a 11ttle theatre ortanization wa presented to interested members of the Alumae, and out of their enthusiasm grew what was then called the Nazareth College Theatre Guild.

Change During the summer of 1933 the name of the organization was of Name chenged to the Catholic Theatre Gulld of Iouidrille, and the soope of the Club was widenod to make it civic. 2 Two years later in February of 1935 the Guild was Incorporated and became the Catholic Theatre Guild of Louiaville. Incorporeted, under which title it is still operating.

Hational When the Catholic Theatre Conference met at Chiosgo in June, Afriliation 1937 and at Washington, D.C. in August of the same yoar the Cathollc Thestre Guild sent delegates, and when the Conference was orgenlzed the Club bocame a charter member and its director was appointed regional ohaiman for the Kentucky-Tennessee Area.

\footnotetext{
1. 1 survey of Catholic Particlpation in dramatic production was made at the Catholic Theatre Conference held in Chicago, June, 1937. The surveg Indioated that more than five hundred Catholio organizatione in the United States were engaged in little theatre work.

2. Courier-Journal, Julg 29, 1938.
} 
Ont1l the sumer of 1933 when the Guild changed its name, the membershtp of the organization was limited to graduates of Hazareth College and young men whom they Inrited to be members. When the Galld decided to become a civio theetre, memberahlp was thrown open to any Catholic in the diooese; howerer the Culld retained the right to reject any applicant who for any reason was considered undesirable. ${ }^{1}$

Organization When the Guild was inoorporated, the aystem of gorernment was somewhat altered. Until that time the executive committee hed been composed of president, vice-president, secretary, treasurer, as woll as atage, business, and publicity managers; all of these offlcers had been elected by the general body. It was found, however, that members elected to technical offices were not alwaye quallfled to fill them henoe under the new organization the executive cormittee is made up of the customary four offioespresident, vice-preaident, secretary, and treasurer - and four members at 1arge, all of whom are elective except the seoretary. Th1s latter office together with the more technioal offices are filled appolntment of the exeoutive committeo.

There are four other appointive offloes which are filled by non-Guild members, namelys adviser, moderator, chaplin, and director. They are ex-officio members in an advisory capacity. The director, of course, is responsible for the production of all publio presentations.

The organization has found that much of 1 ts work can be done by standing committees, the foremost of whioh ares the membersh1p, telephone, plagreading, and social committees, whose dutie are self-explanatory. One other combittee deserves a word of explanation; that 18, the specialty

1. Such qualifications as character, ability; experience, and temperament are considered. 
ocmittee whose duty is to have prepered at all times short skits, monologues, and one-aot pleys which can be sent out, on request, to varlous parish organizations deeiring entertainment at their meetings.

The Gulld, too, has its position of honor. The title of Trouper is bestowed on the member who couples outstanding work in any field of production with character and integrity. Bach season one member is raised to the honorary office by secret rote of the members, and the title is conferred, with an appropriate ceremony, by the director who is the Grand Prouper.

Production During the first season the Guild operated at Presentation Problems Lcademy Auditorium. The difficulties encountered in producine plags on thst amall, none too well equlpped stege, together with the fact that as it was located on the top floor all properties and furniture used had to be carried up and down three flights of stairs, caused the organization to move to the Woman' Club for the next season. The ten-foot scenery bullt for Peesentation' - Auditorium was wholy inadequate now, and it was necessary to discard it and construct new equipment.

The lack of an auditorium of its own has handlcapped the Guild from the beginning. Both the Woman' Club and Columble Auditorium where the Guild operated for three sessons, are avallable to the public which means that the Guild can have rehearsals ${ }^{2}$ only when nothing else is scheduled, and that scenery can be built only when the stage is not in use. 2 The organization has prectically no time for experiment; yet its settings have been athentic and attractire. Perhaps the most experimental set devised by the

1. Rohearsals also entall additional expense.

2. There have been occalions when the Guild having scheduled a dress rohearsal for Friday night and performance for Sunday night, has had to strike all settings, properties, eto., on short notioe, for programs coming tnto the auditorium on Saturday. 
Gaild is that used for the production of the Lenten plag, Poce spmue Del. This is a soulptural set consisting of five parallels of two levels, around the lower level of whioh is built two-tread atairs, thus effecting a three level stage.

Iighting

and

Sound

The Gulid has found that elaborate or lavish scenlo effects are almost the same effect can be produced by the use of pot 11ghts. The Lenten production is lighted by spots only, change of arrangement either accentuating the eimplicity of the setting or creating an impression of the elaborate. 1 The production of the Ghost Train, ${ }^{2}$ carly in the Guild's careor, demonstrated the importinoe of sound effects, and The First Logion showed the neosesity for music o oncurrent with the acting. The building of equipment to produce the sound effects was possible, but having no orchestra of its own. the Gulld found the problem of music more diffloult of solution. Both problems, however, were solved by purohasing a complete sound system which includes miorophone, amplifier, phonographic pick-up, and three loud speakers. 3

Ouild

and the

Publ10

The Guild is, of necessity, self-supporting; and one of the most effective means of insuring season is the sale of

serson

tickets conducted by direot-by-mall solioitation, sales by individual members, and by a method that proved very effective during the first few years of the Gulld' career - trouplng one-act plays. 4

1. The Iatt Supper scene in Ecoe Arnus Del was played behind ourtain of black oheesecloth. The only lights used in this scene were behind the curtain, thus dopth and beauty were added to the ploture.

2. For this play a spoial Iight machine was constructed, which produced the effect of train cosches dashing past the station.

3. This equipuent cost $\$ 225$.

4. The Heimbors, with two casts, was presented without cost to over forty parishes in Iovievilie and the rieinity. Thie plan was started in 1933 and continued for three sumers. 
Plays One of the most difflcult tasks facing the Guild is the choice of plays. Guild plays must have box office appeal and at the same time be free from any controversial matter in morals or philosophy. ' For this reeson each prospective plag is read by the direetor, moderator, and the chaplin before a final deolsion is made. This method provides a gurd against mistakes from three angles: dramatic, moral, and philosophical.

1. Is careful as the Guild 1s, complaints are sometimes made. One peraon -tremuously objected to the title of The Blohop Misbehares. 
CHAPPR VI

MUAICIPAI ACPIVITY 
VI

\section{Inaiolpal sotivity}

Heishborhood One of the first entearore in little theatre production in House

the United States came by way of the oettlement house, 1 and Louisvile was one of the first citles that fostered settlement work. No treatise of Louisville'. little theatres would be complete without some mention of drametic activity in the Loularille recreational conters and settlement houses.

Dramatic actirity at Neighborhood House was organized in 1924

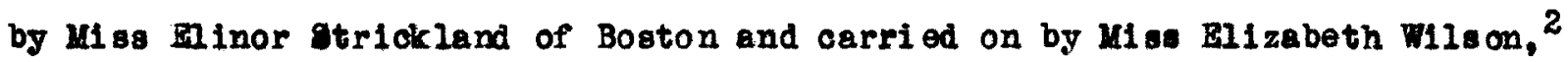
Who was appointed the following year to take Miss Strioklend's place. At the beginning of this activity no epeolal group was formed, each olub in the settlement being trained to perticlpate in the plays produced and to do some creative things in the playwrighting 11ne. The Community Plajers Club, an active group which interspersed one-act plays with social events, was soon formed at Neighborhood House, but its actlvity did not prevent the other clubs from engaging in dramatic work. They also built scenery, made costumes, and constructed lighting devices for their performances.

Children's During 2930 the Children's Theatre Gutld was organized and Theatre

Guild cont inued operations for two sessons; at the end of this time It became apparent that the organdzation was not self-supporting. An effort was de to analgamate this group with the Iittle Theatre Company, but the Iftle Theatre had just been organized and was not ready for such an undertaking. Since the union could not be effected and since the Gulld oould no longer operate under its own power, the organization was discontinued.

1. Keclowan, Kenneth, op. cit., pp. 47-50.

2. His. Wilson received her early training with the University of Loulsville Players. Sho also took a course in drame and ohild technique at the Chicago Recreation Sohool. 
Oity'

Reoreation

Department
Dramatio activity under the auspicen of the City's Recreation Department was epasmodic until 1932. During the summer of that year, Miss Wilson, who had been appointed inatructor in dramatice, inaugurated a pley contest among all the playgrounds. This work was so successful that dramatio activity in the Recreation Depertment developed under three olassifications: nummer plegerounds, communtty centers, and the service bureau.

The sumer playground activity began in 1935 when dramatic groups with very flexible membership were organized on prectlcally overy playground in the city. These groups dramatised folk tales, gave pleys on their own pleygrounde, and took plays to Central Park, where the finals of the playground contest were held.

In IIne with these contests, the one-act play tournament which the Department conducted in 1932 was opened to any group in Louigville. Thit activity has grown steadily both in participants and audience until it was necessary in 1936 to divide the groupe into junior, senior, and open conpetition classes.

During the sumer of 1933 the Playmakers of the Division of Recreation took the Birthday of the Infante to the Century of Progress where it was presented at the Children's Theatre on Enchented Island in Chicago. The next few aessons found the playground etreseing dramatic activity along definte Iines, in 1934 Indian folk lore predominated, in 1935 the Arablan Hights were the subject of interest, and in 1936 the Kentucky ploneer storieo offered educational as well as dramatic possibilitiea.

The winter activity of the Department of Recreation has been concentrated in the comanity contere where amall dramatic clubs for all-age groups have been formed and plays frequently given. To foster this activity several institute have been held in the city by the National Recreation 
The phase of dramatic activity desigated as the service Bareau conducts a "Costume Chest" under the direction of a W. P. A. sering profect, which has assembled all costumes used in the various plays and pagents given at Central Park. The Bureau has also eatablished a consultant and cosching servioe which has been made arailablo to churches and schools desiring assiatance in dramatics.

These three phases of activity hare not occupied the entire attention of the Bepertment. Bach Christmas the Department, together with the Layor's Christmas Committee, has sponsored a children's play which was given at one of the downtown theatres; and for three summers programs were presented twice a week over W. L. A. P. and W. A. V. B. radio stations under the title of Peter and Polly on the Plargrounds. In 1936 the Junior League In cooperation with the Department presented The Christmas Nightingale at fire Junior High Schools with chlldren from the Recreation Department groupe a) the participants.

Marionette One other phase of activity in settlement houses and playShow:

ground throughout the city deserves mention in any survey of thi topic. Marionette shows ander the unpervision of Thomas Hoonan, an expert in mis field, have been included in the work done by the Department and have added a great deal of pleasure and entertainment to children and also to grown-ups. 


\section{CHAPTER VII}

OHHER CROUPS 


\section{VII}

Other Groups

The phenomenon of little theatre derelopment has been the rise and fall of many groups throughout the country. Some group have been unable to orercome the finanolal difficulties presented; others have been promoted by some one person and when that person's efforts oessed, the organization went out of existence. Still other groups, being unable to justify their existence, have died through their own Ineffectualness.

Louls ville has had its little theatre organlzations which have rusen, and after a briet carear, have ceased to exist. ${ }^{1}$ Other olube have had and continue to have, a spaemodic activity, giving an occasional play but haring no definite 11 ttle theatre existence. ${ }^{2}$ for the sake of completeness, we must consider these endearors.

Columbia One such organization was the Columbla Players which was founded Plajers by members of the Loulsville Council of the Knights of Columbus in 1929, and being an organization within an organization was hampered and finally killed by over-adminiatration.

Loulaville Soveral members of the Columbia Plegers who wh shed to continue Civio Theatre setivity in the little theatre field organized new club whioh wac called the Louisville Civic Theatre. Before it ceased operation the new olub produced eighteen plays in four sessons. There mere two contributory reasons for its fallure: 1ts last active season, 1936-1937, was not financially successful, and it did not have one direotor in whose hands the entire

1. The Chlldren's Thestre Guild was such a sroup.

2. Suoh a group is the Pederal Pleyers formed by employees of the Government, who usually present at leat on play mol season.

3. The organlzation was actire for two seasone. 
responolbility of production was reposed. 1 Lfter a lapse of one year the club tried to reorganize and did sucoed in promoting several radio programs over W. G. R. C. broadcasting station, but to date that ha been the final effort.

Blackfriars One little theatre known as the Louleville Chapter of the BleckGusld

Friars Guild deserves to be mentloned at least for the idea behind its inception. The Blackfriars Guild was founded in Washington, D. C., 1n 1934, W1 th the idee of building a netional 11ttle theatre under that name. ${ }^{2}$ The Louisv1110 Chapter was ostablished in 1935 by Rev. S. D. Rooney, O. P., who was its director. The group produced two plays ${ }^{3}$ and disoontinued actirity, probebly beceuse its director was transferred from Louisville, and the Club had not been in existence long enough to have solidified its adminlatrative organization.

Y.H.H.A. Since the rise of the movement the Young Men's Hebrew Associetion of Louisville has supported a little theatre group at various times. A regular program of plays was presented during the 1980-1981 season, and the group showed sane activity during the following season, but no definite sustained little theatre has resulted from this organizati on.

Sacred Sacred Heart College, a Junlor College for women, has been Heart active in dramatic production, but the institution does not have a little theatre group, playe being produced under the auspices of dfferent classes and clubs during the sohool year.

1. I managing director was appointed for the season but did not engage in. the sotive direotion of each play, nor was he renponaible for those productions which he did not direct.

2. The Blaokfriars Guild is atill in existence a anit of the Cathollo Theatre Conferenoe and has over baty chapters throughout the United States. 3. The Monsi mor's Hour and Jorous Season. 
School

Aotivity
The sohonls of Louisvilie have included drematics among their extra currioular actirities, but there is no superintendent of

Dramatic activity in the Louieville sohool system nor in the Parochial schools. This,however, has not deterred the dramatio sotivities of the schools. Plags are given more or less regularly, usually under the direction of a regular school tesoher at the sohool; and the sentor clase play has become a tradition in most of the high achools for girls.

Parioh Dramatio

Parlsh dramatics in Loulsville have inoreasgd steadily. The White House report made in 1933 states that of the 90 Protestant Churches aurveyed, 40 reported regular dramatic activity. Many Cathollo parishes, too, have regular dramatio ectivity; some have dramatic clubs, while in others plays are produced by clubs and sodalities. 
GHAPIER VIII

CONIRIBUTIONS 
VIII

Contributions

The little theatre movement is essentially a rerolt againat commercial domination because ittle theatrea are establiahed for love of drame and not for gin. The cohtributions of the little theatre in Loulsville, as well as at large, oan be divided into the influences on participants and communtty influence. The influence on partiolpants is relatively greater than that on the community because the former 18 direct while the latter is indireot or reflected.

An Idjunct In the profoselonal theatre the opportunity for partiolpation of Deduation is afforded to comparetively fow but in the 1ittle theatre there 1s both room and work for al 1 who are genuinely interested in ang phase of production; hence particlpation in 1ittle theatre activi by presents a natural means of education for the individual. The degree of this educative influenoe is dependent upon the indiridual but the possibilities are unlimited. Thile Louisville's little theatres do not intend to train people for the profession, ${ }^{2}$ the fact that they have been stepplng atone sor meny is indloative of the adequacy of individual training. The elucative influence upon the comminity is less tangible in that it is produced either through the results of the finished production or by the influence of the individual partiolpant upon those with whom he comes in contact.

Appreciation Closely allied to the eduontional influence of little theatres 1.8 of Dram the increase in the capacity for appreoiation and enjoyment of drame resulting on the one hand from activity in the production 
of pleys and on the other from eeelng good playe well done. It becanes inoreasingly difficult for trained partiolpants or apectators to find any entertaiment value in a second-rate play or production. ${ }^{1}$

Social Since active participation in little theatre work is conducire Influence to objectire al well as subjectire stimulation, the social inPluenoe is of no little importance. One of the greatest contributions of the 11ttle theatre to the participant is the pleasurable and profitable employmont of letare time in the company of others actuated by the same motives. Howerer, this fact mag lead to a 108 of. community influence if the participent becomes so engrossed in the activity that he foregoes all othera, thus IImiting his cirole of aoquaintances to his fellow-workor in this particular field. ${ }^{2}$

Keeping Although Louigville' little theatres were not formed with the the Drams Idea of supplanting the professionel stage, the decline of the Alive "road" ha lead to the production of ourrent Broadway hits in an effort to keep the oity informed of the latest developments in drama. This actirity leares but little time for the experimentation and original production so much to be desired in little theatre work, horerer, these orgenizations are fulfiling their mission in that they are kepping alive the spoken drama ctemplified on the tage.

since the 11ttle theatre came into being in Loulaville, the public response to the movenent has been little disappointing; it is obvious that a large part of the audience come to see the players rather than the play; however, it is to be hoped that a a reault of the gradual education of the 
pablic the little theatre audiences will be recruited from a larger group of people who here some genulne interett in the theatre.' That ouch a group is being formed $c$ an be readily seon from the oteadily increasing unsollcated boxoffice sales. Furthermore this formation proves that the little theatre has taken a definite place in the cultural pattern of the city, and that the future of the morement is relatively assured by the support of this additional audience.

There secms, at present, to be a sight tendency towards the return of the "roud", which if it is successful, w11l change the entire future of the little theatre because the obvl ous box-offloe shore will be done here professionalig, thus giving the little theatre an opportunity to become an experimental laboratory wherein revivals, experi ments with modernist teohnique, and first performances are given equal opportunity. There are many things to be desired for the future of the movenent in Loulavilie, foremost of which is the revival of the Children's Theatre accompanied by the appointment of a supervisor of dramatic ectivity in the sohools. In the University a department of drametic at having at its diaposal an auxiliary stage for rehearsal and experimentsil work would do much to further the educettonal and cultural value of the l1ttle theatre. Of no lese importance is the acquisition of a permant home for each of the major producing organizations in order that they mey wre an opportunity to follow out to their logical conclusion such experiments as have been mentioned as well as those of a more technical nature.

1. Ietter from Berry Bingham to Fred Karem, September 1, 1937. 
CONCLUSION 


\section{Conclusion}

The derelopment of the little theatre in Iouferille exemplifies practically erery phase of national or international derelopment in that the olty has organizations representative of each of the four major phasea. In the fiold of the oivic community theatre there i the Ifttle Theatre Company; groups representative of the little theatre in institutions of higher learning are the University of Loulerille Players and the Roswithe Dramatio Olub of Fazareth College; the Catholic Theatre Gulld of Loulaville typifies the little theatre from a religious aspect; and the settlement littlo theatre influence comes through muniolpal sotivity in community and settlement centers.

These representatives of the four phases of Louisville's little theatre development have meintal ned their non-comercial aspect and have just1fied their existence by engaging in occasional experimentation resulting in new and unusual plays and by being dedicated primarily to the study of drama and dramatic art. Their activity in the study of drama has erolved a comparatively high atandard of productions as an examination of the titles of plays produced reveale that the majority of them have been written by authors of the first rank.

LIl of Louisille's existing little theatres have been successful in dealing with the three major problems confronting them, those of organization, production, and public relations. Howeror, the high efficienoy attained by Ioulavilie's 11ttle theatres in the mechanice of production has, thus far, been their greatest aohievemont. 
APPENDICES 


\section{Appondix A}

WNOR PRODUCTIONS OF THE UIIVERSITY OP IOUISVILLE PLAYERS *

PIAYS

Ldam and Era

Admirable Crichton, The

A110e-S1t-By-the Pire

Anchore

As You Ilke It

B1. Idea, The

B112r

Bonds of Interest, The

Bor Moets Girl

Chains

Children of the yoon

Oninese Pazzle, The

Cralle Snatoher, The

Cradle Song, The

Crime at Blossome

Der11's Digc1ple. The

Dol1x Reforming Hereelf

Don

Double Door

Dover Roed, The
ATHAORS

Bolton and Middeton

Sir James Barrie

Sir Jemes Barrie

Ro110 Dayne

W111am Shakespeare

Clayton Hanilton

George Cameron

Jacinto Benewente

Bella and Sanuel Spowack

Mizabeth Baker

Martin Plavin

Marion Bower

Boyd Martin

G. Martinez-Sierra

Yordant Sharpe

George Bernard Shaw

Henry Arthur Jones

Rudolph Besier

Hisabeth McPadden

A. A. Milne
SEASOR

$1933-1934$

$1917-1918$

$1935-1936$

$1928-1929$

$1937-1938$

$1925-1926$

$1929-1930$

$1924-1925$

$1987-1938$

$1927-1928$

$1926-1927$

$1923-1924$

$1916-1917$

$1932-1933$

$1932-1933$

$1926-1927$

$1925-1926$

$1923-1924$

$1934-1935$

$1924-1925$

\footnotetext{
"Complled from Mr. Boyd Martin's records and screpbooks.
} 
H18s Comes to Star

Pnemy of the People. 스

Engered

Expessing P11110

Fenny and the Servant Problem

Garden of Memoriee, The

Goose Hange High, The

Green Stookings

Orumpy

Grpey Tre11, the

He118 Bel18

He11 Bent Por Heaven

Hor Husband's wife

Her Woutern Rempo

Hobson's Ghoice

Honermoon, The

If Pour Palls Told

I'11 zeave It to You

It Hover Raine

Importance of Being Earneat, The

Irory Door, The

Jeok Straw

Just Suppose

June Yoon
H. V. Femond

Henrik Ibsen

W. s. G1lbert

Raohel Crothers

Jerome K. Jerome

Fred J. Xarem

Lew1 Beach

A. H. W. Heson

Horace Hodges

Robert Housum

Barry Oonners

Hatcher Hughea

A. E. Thomas

Stdney Toler

Harold Brighouse

J. Tobin

Bdward Peroy

Nool Coward

Aurania Rouverol

Oacar Wilde

A. A. Milno

V. Somersot vucham

A. E. Thomas

Ring Lardnor
$1919-1920$

$1923-1924$

1934 - 1935

$1917-1918$

$1928-1929$

$1933-1934$

$1930-1931$

1918 - 1919

1924 - 1925

$1930-1931$

$1928-1929$

1925 - 1926

1921 - 1922

$1929-1930$

1923 - 1924

1918 - 1919

$1928-1929$

1926 - 1927

$1931-1932$

$1983-1934$

1938 - 1934

1934 - 1935

$1923-1884$

$1932-1933$ 
Rompy

K10k In

Itttle Women

Mame's Affeir

Nary the Phird

Hice and Mon

Mid numer Might's Dream

Miniok

Yr. Pim Pespes Br.

Yrs. Partridze Presents

Monne Vanne

Much sdo About Mothing

Mr Iedr's Drese

Mine T111 S1x

Iothing But the Pruth

이 Iadr 31

Onls 38

Othe110

Paole and Francesos

Perkins

Foldas

P111ere of Soc1etr

Plarbor of the Western World, The

Post Road

Pursuit of Heppiness, The
Nugent and Nugent

$1931-1932$

Willard Naok

$1931-1932$

Loul an Aloott

$1922-1923$

Rachel Butler

Rachel Crother:

Madeline I. Ryley

W1111 am Shakespeare

Kaurman and Ferber

1. A. Milne

Kennedy and Hawthorne

Yaurioe Maeterlinck

William Shakerpeare

Edward Knoblook

Limee and Philip Stuart

James Montgomery

Rachel Crothers

A. E. Thomas

Dilliam Shakespeare

Stephen Phillipa

Douglas Murray

Rollo Vayne

Honrik Ibson

J. M. Synge

Strele and Mitohell

Iangmer and Langner
$1922-1923$

$1926-1927$

$1915-1916$

$1919-1920$

$1925-1926$

$1935-1986$

$1927-1928$

$1921-1922$

$1935-1936$

$1928-1929$

$1930-1931$

$1984-1985$

$1934-1935$

$1922-1923$

$1929-1930$

$1927-1928$

$1929-1950$

$1916-1917$

$1922-1923$

$1936-1937$

$1937-1938$

$1986-1937$ 
Rol11ng Stoned

Romantic Young Lad,. The

Romeo and JuI1et

Sorep of Paper. 1

Secrets

Seren Sisterg

Serenteen

She Stoops to Conguer

Skx Rooket. The

Spring Dance

Suocessul Calamitr, 1

Swan, The

Terern, The

Taming of the Shrew. The

Temper and temperment

Thousend Ieers $40, \Delta$

Three-Cornered Moon

Irelawner of the We118"

Pruth, the

Two Orphans, The

Ugly Drok 11n: The

We're Got to Have Monery

When Rnishthood was in Flower

Eladom Tooth, The

You Horer Can Tell

Iounsost, The
Onknown

G. Martinez-Sierra

Wi1liam Shakeapeare

Viotorion Sardou

Besier and Bdglation

Edith Ell1s

Booth Tarkington

Oliver Goldemith

Mark Beed

Philip Barry

Clare Kumper

Parneo Molner

George M. Cohan

Tilliam Shakeopearo

Boyd Martin

Percy Maoxaye

Gertrude Tonkonogy

Sir Arthur Wing Pinero

Clyde Pitoh

Adolph D' Pmery

Boyd Martin

Bdrard Iaska

Paul Kestor

vare Connelly

George Bernard Shat

Fnilip Barry
$1927-1928$

$1927-1928$

$1926-1927$

$1916-1917$

$1981-1932$

$1937-1938$

$1924-1925$

$1922-1925$

$1980-1931$

$1936-1937$

$1924-1925$

$1925-1926$

1934 - 1935

$1930-1931$

$1920-1921$

$1929-1930$

$1934-1935$

$1918-1919$

$1921-1922$

$1936-1937$

$1920-1921$

$1932-1933$

$1932-1935$

$1931-1932$

$1914-1915$

$1933-1934$ 
Append1x $B$

LION'S CLOB PRIZE WINARER *

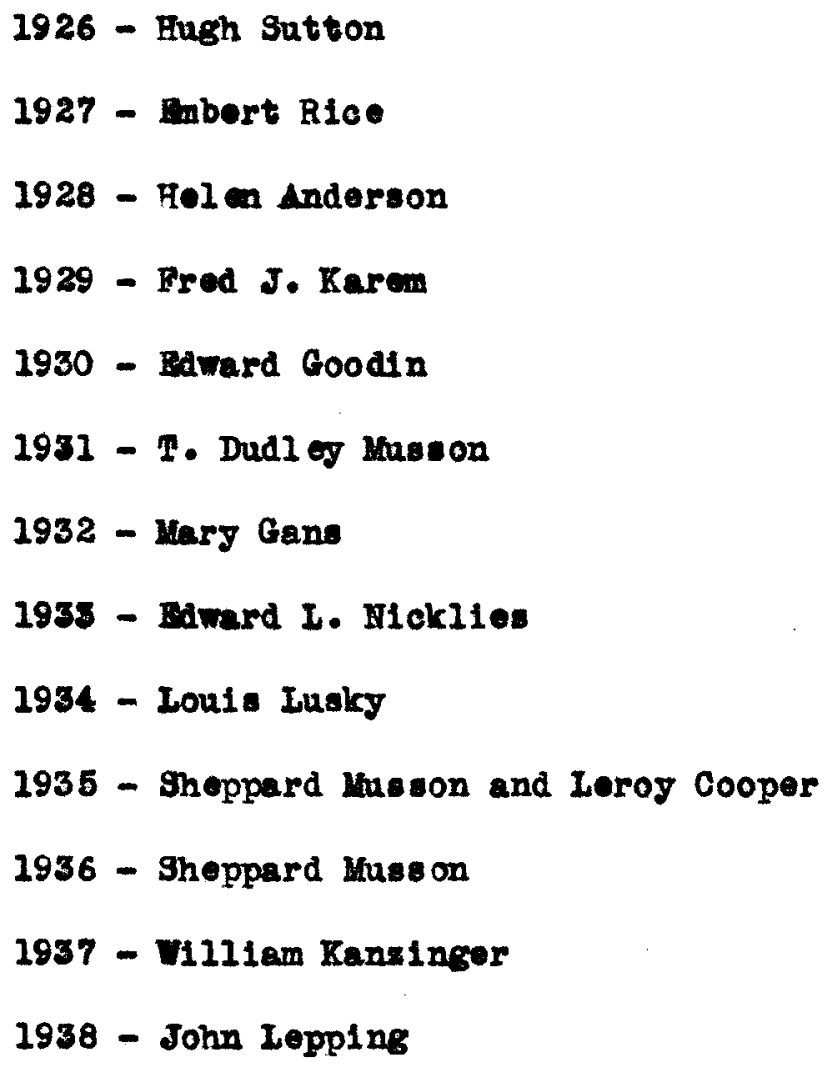


Appendio $\mathrm{C}$

PLAYS PRODUCED BY THE ALUMAI PLAYERS *

PLAYS

Bird in Hand

Boomerang

Constant Wife, The

Copperhend, The

Cricket of Peling Dey, the

Dear Brutus

Heleng's Bore

Just Hike Judy

Men 置th a Logd of Mischief

Ol rupie

Pigeon. The

Polly With a Past

Selt Dater

Sohool for Soendel, The

Truth About Blayds, The

Fodding Bells

Domen'e Wer, $\Delta$
AUTHOR

John Drinkwater

Snith and Mapes

v. Somerset Ioncham

Auguetus Thomas

Auguetus Thomas

Sir Jamee M. Barrie

Ida I. Mrlich

Ernest Denny

Ashley Dakes

Forneo Molner

John Galoworthy

Middleton and Bolton

Golden and Jarrett

Riohard Brinsloy Sheridan

A. A. uline

Salisbury Field

Thome Buchenan
$1929-1930$

$1927-1928$

$1928-1929$

SEASON

$1930-1981$

$1930-1981$

$1950-1931$

$1927-1928$

$1981-1932$

$1928-1829$

$1929-1930$

$1928-1929$

$1929-1930$

$1931-1932$

$1927-1928$

$1927-1928$

$1931-1932$

$1927-1928$

Complled from Mr. Boyd'Martin's records and corapbooks. 


\section{Appondix D}

PLAYS PRODOCED BY THE IITPIE THEATRE CONPANY *

PIAYS

socent on Youth

And So to Bed

Animal Kingdon, The

Berkel ex Square

Brief Moment

Can1110

Cirole, The

Common Olay

Damsel in Distress, The

Dangerous Corner

Diens's Plar

P1) $\triangle$ War Home

Front Pexe

Per Rever

KInd Iadz

Iate Ohrlatopher Bean, The

Lomberd1, Itd.

Iucky Sam Yocarver $\triangle$ UMTOR

Samson Raphaelson

James B. Dagen

Pnilip Barry

John I. Balderaton

S. N. Behrman

Alexandee Damse, Fils

7. Somerset Nougham

Cleves KInkead

Hay and Wodehouse

J. B. Priextieg

Credo Harris

Bennett and White

Hecht and Macspthur

Hoel Coward

dward Chodorov

sidney Howard

Frederio and Fanny Hatton

Sidney Howard
SEASON

$1935-1936$

$1936-1937$

$1936-1987$

$1932-1933$

$1934-1935$

$1933-1984$

$1937-1938$

$1937-1938$

$1932-1933$

$1987-1938$

$1933-1934$

$1935-1936$

$1937-1938$

$1934-1935$

$1936-1937$

$1936-1937$

$1933-1934$

$1932-1938$

\footnotetext{
- Compiled from Mr. Boyd Martin's reoords and serapbooks.
} 
Warch Heres

Mre. Moonl1ent

Ono Sunday 1fternoon

Perfect $111 \mathrm{bi}$, The

Pett10ont Influenee

Quen Was in the Parlor, The

Romange

Rorel Panily

See replen and Die

Small Miracie

Stare Door

Tind and the Rain, The
Harry W. Gribble

$1934-1935$

Bonn W. Lory

$1935-1936$

James Hagan

$1934-1935$

A. A. Milne

$1933-1934$

Hoil Grant

$1933-1934$

Hoel Coward

$1936-1937$

Rdward Sheldon

$1935-1936$

Raufman and Porber

$1932-2933$

Elmer Rice

Iormen Krasna

Kaufman and Forber

Morton Hodges
$1932-1933$

$1935-1936$

1937 - 1938

$1934-1935$ 
Appendix B

PLAYS FRODUCED BY THE ROSWITHA DRAMATIC CLUB *

FIAYS

Adrentures of Ledy Orala, The

Blossoming of Mery snne, The

Certle Comedr. The

Don't Count Your Chiokens

Gorrman

Pleme Leepe Up, The

Goodnatured yen, The

Genntlet of Faith. The

Iittle Women

Iadies in Waiting

Yoneleur Benostre

Iot So Iong Aso

Per OI Hr Heart

Pomander Walk

Quality gtreet $\triangle$ UTHOR

Anthony Hope

Mar1on Short

Thomas Brohanen

W11bur Braun

Anonymous

Daniel 4. Lord, S. J.

011ver Goldamith

Dorothy Painter

Ioulsa Aloott

Cyrtl Campion

Booth Tarkington

Arthur Richman

J. Hartley Manners

Louis N. Parker

Sir Jemes U. Barrie
SE1SON

$1925-1926$

$1931-1932$

$1926-1927$

$1934-1935$

$1927-1928$

$1950-2931$

$1934-1935$

$1923-1924$

$1931-1932$

$1935-1936$

$1930-1931$

$1925-1926$

$1932-1938$

$(1924-1925)$

$(1932-1933)$

$(1928-1924)$

$(1936-1937)$

\footnotetext{
Complled from minutes, reoords, and sorapbook of the Roewithe Playere.
} 
Rivele, The

Bomaneere. The

She Stoops to Conguer

S15 P012x

Smi11n' Throuch

Trelower of the WTel18"

Twelfth N1sht. The
Rlohard Brinsley Sheridan $1929-1930$

Mond Rostand

$1929-1930$

Ol1ver Goldomith

$1927-1928$

Daniel A. Lord, S. J.

$1950-1931$

Allan Iangdon Mertin

$1937-1938$

Sir Arthur Wing Pinero

$1928-1929$

Wi111am Shakespeare

$1935-1936$ 
Appendix

PIAYS FRESEINERD BY THE GATHOLIC THEATRE GUID OF WOUISVIILE *

PLAYS

Applesauce

Adem and Fre

Behold the Lamb

Bif Hearted Eerbert

B1shop Misbeheves, The

Broken Di hee

Cinderelia's Grandmother

Boes smus Dei

Penner and the Servant Problem

Plrat Ierion, The

Ghost Train. The

Growine Paing

Importance of Being Ramest. The Oscar Wilde

Booth Tarkington

Zone Galo

Ne1phors, The

Pessing of the Third Floor Book

AUPHOR

Barry Conners

Bolton and Middleton

Daniel A. Iord, S. J.

Sophie Kerr

Prederlok Jackson

Uartin Fiarin

Fred J. Karem

Pred J. Karem

Jerome $\mathrm{K}$. Jerome

Bumet Invery

Arnold Ridey

Aurania Rourerol

Intimate gtrangers
$1987-1938$

SPASON

$1933-1934$

$1932-1935$

$1934-1935$

$1935-1936$

$1937-1938$

$1937-1938$

$1936-1937$

$(2935-1936)$

$(1936-1937)$

(1937 - 1938 )

$1934-1935$

$1936-1937$

$1934-1935$

$1935-1936$

$1931-1932$

$1933-1934$

$1932-1933$ Gulld.

Complled from minutes, sorapbook, and reoords of the Cathollc Theatre 
Bemote Control

Roed to Bethloham. The

Seren Kers to Beldpate

Shannons of Brosdvey. The

Skidding

So This Ia Iondon

War of Sorrons. The

Didow in Green, $A$
Tuller and Jackson

Fred J. Zarem

George M. Cohan

James GI eason

Aurania Rouverol

Arthur Goodrioh

Fred J. Karem

Lea Proeman

$$
\begin{aligned}
& 1936-1937 \\
& 1984-1935 \\
& 1938-1986 \\
& 1934-1935 \\
& 1933-1934 \\
& 1932-1933 \\
& 1933-1934 \\
& 1933-1934
\end{aligned}
$$




\section{Append ix 6}

PLAYS FRODUCED BI THR LOUISVILLE CIVIC THEATRE *

PIAYS

Alarm Clock, The

Bed ung. The

Barker, The

Best People. The

Find of the Tre11. The

Pnemr. The

Joneer

Just Suppose

Looge Moments

Ionder Pleage

Nancr'a Private Lffair

How Come the Plaintiff

On Triel

Petgr, The

Sol1d South, The

Squal1, The

Take My 1 drioe

Th1s Thing Called Love
AOMHOR

Avery Hopwood

Porter Emeraon Browne

Kenvon Micholaon

Gray and Hopwood

Unknown

Channing Pollock

Morrison and Foohey

1. I. Thoms

Serage and Hobbs

Norman Krasma

yyr on C. Pagan

Grace Ruthenburg

Hiner Rice

Barry Conners

Iawton Campbe11

Jean Bart

Bilott Lester

Edwin Barke
SPMON

$1938-1934$

$1935-1936$

$1934-1935$

$1934-1935$

$1932-1935$

$1934-1935$

$1233-1934$

$1935-1936$

$1935-1936$

$1935-1936$

$1932-1933$

$1985-1936$

$1933-1934$

$1933-2934$

$1938-1934$

$1933-1934$

$1934-1935$

$1934-1935$ 


\section{Appendix E}

IIST OF PLAYS PRODUCED BY THE PLAYERS CIUB *

PIAYS

Anthong and Anns

Lrizona

Diplomacy

Fann's Pirst Plar

Ho Who Gets S1 spped

Ioe Bound

John Permon

Lady Windemere'g Pan

Purpie Beast

Sueen's Husband

R. U. $\underline{\mathrm{R}_{0}}$

Becret Bervice

Sun $U_{0}$

Sreme B1rd

Ther Knew What Ther Manted

Toroh Bearers, The

Witeneaded Bor, The
AUTHOR

St. John BrTine

Augustus Thoma:

Viotoriem Sardou

George Bernard Shaw

Andreyer Loonid

Oren Devis

St. John Invine

Oecar Wildo

Bonne Dunkerson

Robert Sherwood

Karaz Capok

Miliam Gillette

Iulu Vollmer

Cale Young Rice

Sidney Howard

George Kel1y

Ionnox Robinson 


\section{Sppondix I}

LUHHORS OF PIAYS PRODUCED BY IOUISVILLE'S LITTLE THRATRES

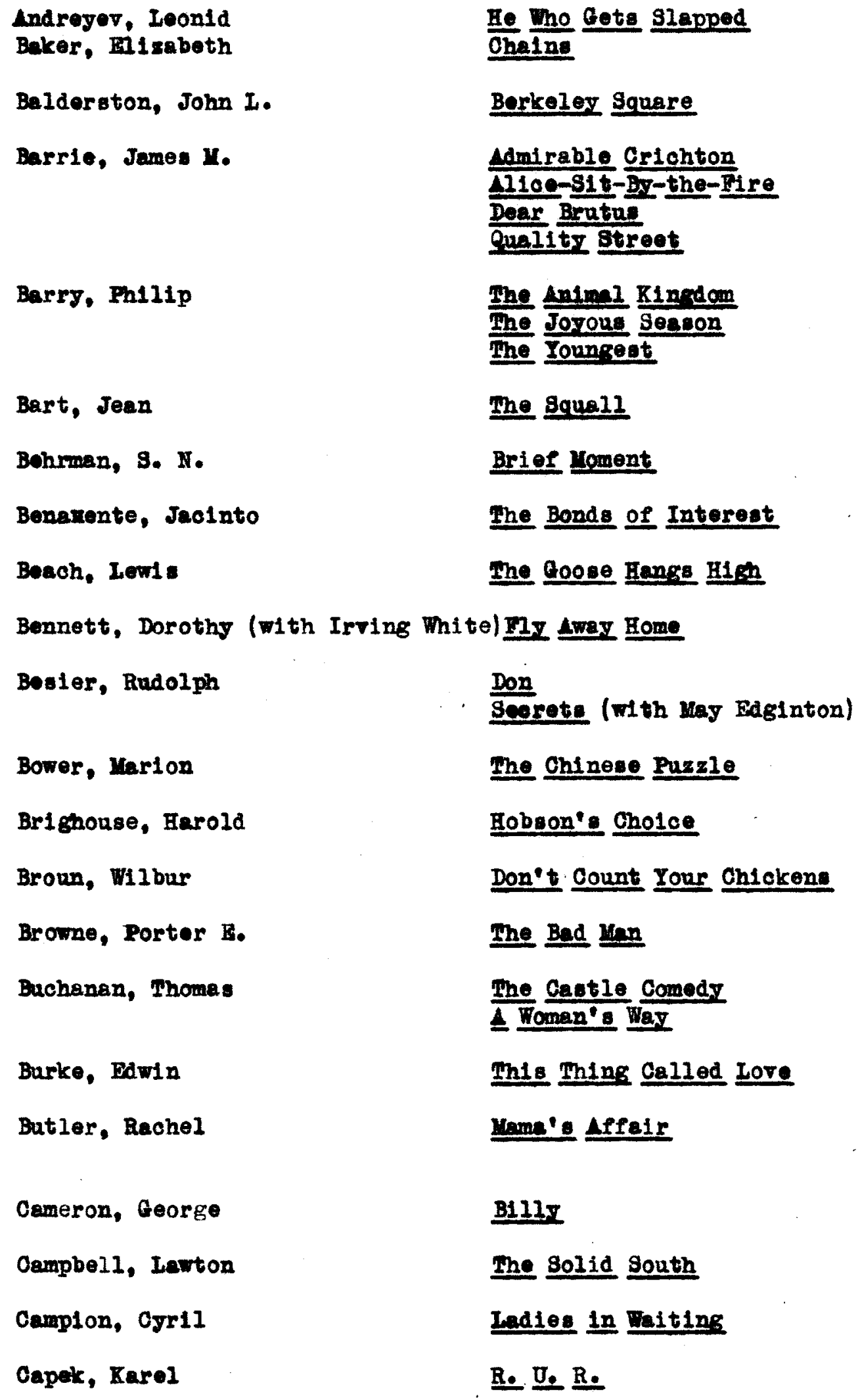


Cohan, George $\mathrm{M}$.

Connelly, Mark

Conners, Barry

Coward, Noel

Crothere, Raohel
Seven Kere to Beldpate

The Tarern

The Wiadom Tooth

$\triangle p p l e s a u c e$

Hel18 Be118

The Pator

Her Borer

I'I1 Leare It to Iou

The Qmeen In in the Parlor

Broressing Hil110

02d Indy 31

Ioebound

The Two Orphane

De Bmery, Adolph (Translation by Hart Jackson)

Denny, Frnest

Just Like Judy

Drinkwater, John

Bird in Hand

Dukes, $\Delta$ ahlog

Man With a Load of Mischier

Dumas, Mlexende, filo

Camille

Dunkerson, Bonne

The Purple Beast

M11s, Fdith

Seven Sisters

Fthrlich, Ida I.

Helene's Bore

Rrvine, St. John

Anthony and Anna John Ferguson

Esmond, B. C.

Fize Comes to Ster

Fegan, Jeme B.

And So To Bed

Fagan, wron C.

Nanor's Prizate Affair

Forber, Eane (with George 3. Kaufman)
Miniok

The Rorel Family

Stage Door

Dedding Belle

The Truth 
Favin, Martin

Gale, Zona

Geleworthy, John

Gilbert. T. S.

Gillette, W111am

Goldemith, Oliver

Golden, John

(with Dan Jarrett)

Gleason, James

Goodrioh, Arthur

Gray, David (with Avery Hopmood)

Hanilton, Clayton

Harris, Credo

Hay, Ian (with P. G. Wodehouse)

Heoht, Ben

(with Charles Macdrthur)

Hod 80s, Horace

Hodges, Merton

Hopwood, Avery

Houewn, Robert

Howard, Sidney

Eughes, Hatcher

Ibsen, Henrik

Jeckson, Frederick

Jerome, Jerome $\mathrm{K}$.
Broken Dishen

Children of the yoon

The Ho1ghbora

The Plgean

Bngeged

Secret Servioe

She Stoops to Conquer The Goodnatured Mnn

Salt Water

The Shannons of Broedwar

So This Is Iondon

The Best People

The Big Idee

Dians's Plar

$\leq$ Damsel in Diatresa

The Front Pege

Grumps

The Wind and The Rein

The Alarm Clook

The Grosy Prail

The Late Christopher Bean

Iuekry Sem Yocervery

Ther Xnew What Ther Dented

He11 Bent Fer Hearon

An Bnemr of the Pcople

The Plilars of society

The Blshop Misbehaves

Panar and the Servant Problem

The Passing of the Third Floor Back 
Jones, Henry Arthur

Karen, Fred J.

Kaufman, Georgo $\mathrm{S}$.

(with Rdna Perber)

KeI1y, George

Konnedy, Mary

(with Duth Hawthorne)

Kerr, Sophie

Kester, Paul

Kinkeed, Cleres

Krama, Morman

Kumer, Clare

Iangner, Iawronce and Armine

Lardner, Ring

Laska, Bdward

Levery. Fimet

Legter, 태 liott

Levy, Benn

Lord, Danlel L., S. J.

Laok, Dillard

Neokaye, Percy

Useterlinok, Inurloo

Yanners, J. Hartley

Mapes, Victor
Dolly Reroming Herself

Clnderella's Grandmother

Eoce Agnus DeI

Garden of Momorleo

Hoad to Bothlohem

Ray of Sorrowe

The Rorel Fand1r

Iiniok

Stege Door

The Towh Beerere

Urs. Partridge Presenta

B1s Hested Herbert

When Knighthood Was in Mower

Common Olay

Small Mirecie

A Successful Calamitr

Purguit of Happiness

cune yoon

We're Got to Have Money

The Firat Leotion

Yone1seor's Hour

Take Ly der1se

Mrs. Moonl1ght

Behold the Iemb

The Flame Ieaps Up

3ix Fo11r

Kicl In

$\triangle$ Thousend Yearg Aro

Lomn Vamn

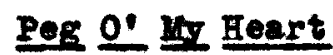

The Boomerens 


\begin{tabular}{|c|c|}
\hline Martin, Allan Langlon & Snilin Throush \\
\hline Martin, Boyd & 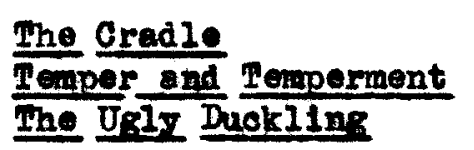 \\
\hline Uason, A. E. Q. & Green Stookinge \\
\hline MoFaddon, Hizaboth & Double Door \\
\hline Yolnar, Fernec & $\frac{\text { O1.rmpla }}{\text { The Swan }}$ \\
\hline Mugham, W. Somerset & $\begin{array}{l}\text { The Cirole } \\
\frac{\text { The Constant Wife }}{\text { Jeck Strer }}\end{array}$ \\
\hline 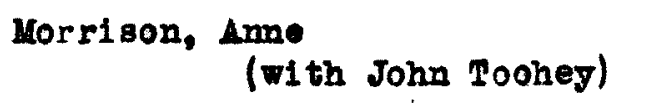 & Jonser \\
\hline $\begin{array}{l}\text { Middleton, George } \\
\text { (with Guy Bolton) }\end{array}$ & $\frac{\text { dam }}{\text { Pol1x }} \frac{\text { and }}{\text { Wing }}$ th a Pant \\
\hline Mlne, A. A. & 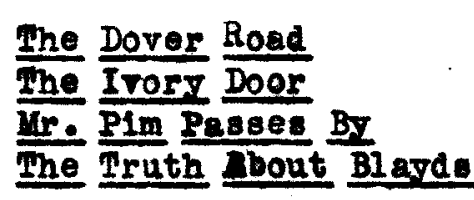 \\
\hline Wontgomery, James & Nothing But the Truth \\
\hline Murras, Douglas & Porking \\
\hline Nicholson, Kenyon & The Barker \\
\hline $\begin{array}{l}\text { North, Clyde } \\
\text { (with Fuller and Nelson) }\end{array}$ & Remote Control \\
\hline Nugent, J. C. and Flliott & Xempr \\
\hline Painter, Dorothy & The Gauntlet of Faith \\
\hline Parker, Iouis $\mathrm{N}$. & Pomander Walk \\
\hline Peroy, Edward & If Four Walla Told \\
\hline Pnill1pe, ŝtephen & Peola and Branoena \\
\hline Pinero, Sir Arthur Wing & Trelawner of the Delle \\
\hline Pollock, Channing & The Pnomy \\
\hline Reed, Mark & The Skrocket \\
\hline
\end{tabular}




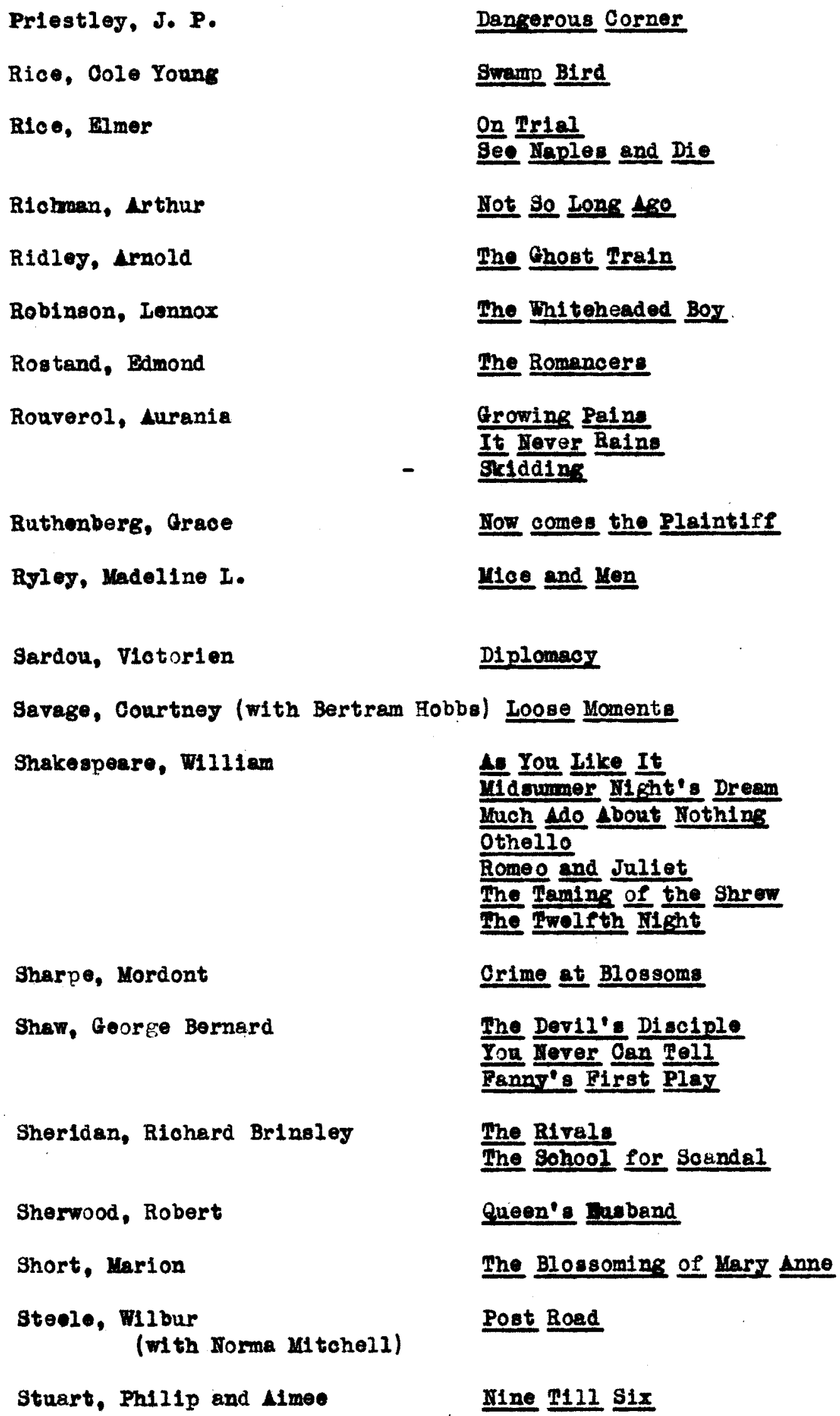

An You Iike It Midsumer IIght's Dream Much Ado $\Delta$ bout Nothins: Othel10 Romeo and Juliet The Taming of the Shrew The Twelfth Hight

Crime at Blossoms

The Deril's Disciple You Hever Can Tell Panny's Pirst Plar

The Rivele The Eohool for Soandal

Queen's Faband

The Blossoming of Mary Anne

Post Road

Mine P111 Six 
Sierra, A. Martinex

Synge, J. M.

Tarkington, Booth

Thoma, A. E.

Thomas, Augustus

nobin, J.

Toler, Sidney

Tonkono6y. Gertrude

Vollmer, Lulu

Weyne, Rol10

Wilde, Oscar
The Cradie Song

The Bomant10 Young Lady

The Playbor of the Western World

The Intimate Strangere

Monaleze Beanceire

Seventeen

Har Husband's Wife

Just Suppose

Only 38

Arizons

The Copperheed

The Crloket of Palmy Days

The Honermoon

Her Western Romeo

Three Comered-yoon

Sun Up

Anchore

Fn1d148

The Importance of Being Eerneat Ladr Windemere' 8 Pan 


\section{BIBLIOQRAPHY}

Books:

Chambers, B. X., the Yedievel Stere, Vol. II. Oxford: at the Clarendon Preas, Henry Frowde, 1903.

Choney, Sheldon, The Ion Yorement in the Theatre How York, Mt tohe 11 Kennerleg, 1914.

Cherey, Shel don, The theatre. London, Hew Iark, Toronto, Iongmans, Green and Co., 1929 .

Hastings, Charles, The Theatre, Iondon, Dubororth and Co., 1901.

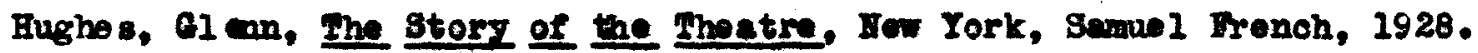

Joffregs, U. V. C. and Stopford, R. W., PIer Production, London, Lotheen and Co. Itd., 1933.

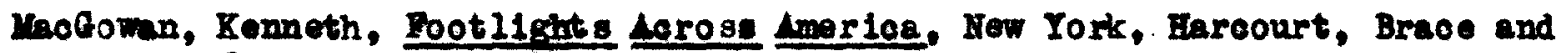
Co., 1929 .

Medky, C. D'Aroy, The Iittlo Theatre In the United States, Few York, Henry Holt and Co., 1917 .

Yimuesipt Reforences

Coll1ne, Si ster sntoinotte, S.C.N., The Drame an Adjunct of Buc ation, a diesertation, Wazareth Coligge, Loulsvilie, $\mathrm{Ky}$.

Scrapbooke of the Univorsity of Loulaville Players in possession of Mr. Boyd Martin, 547 Sumys ide Drive, Loul solile, Ky.

Mnute Book of The Roswi tha Dramatic Club in poseeseion of Fred J. Baren, 315 Loulsville Trust Bldg., Loul or ille, Ky.

Sorapbooks of The Ilttle Theatre Compen in possession of Mr. Boyd Hartin.

Minute Book of The Catholic Theatre Guild of Louleville Incerporated in possesolon of Ulan Inrgaret Driscoll, 1733 Chichester fre., Louleville, $\mathrm{Kg}$.

Sorapbook of The Catholic Theatre Guild of Ioul wille Inoorporated in posseasion of Fred J. Karem.

Records of Drametio sctivity in the Department of Recreation in the offloe of the Director of Dramut io Lotirity, Centrel Park, Louisville, Ky. 


\section{Parcone Intorviewed}

Boyd Yartin, director of The Ifttle Theatre Company and The University of Louis ville Plegere.

Hisabeth Wilson, director of Dramtios with The Department of Reoreation. Barry BInoham, momber of the Board of Bovernore of The Ittte Theatre Company.

Fillam Hoke Canp, former president of the Plavers Club.

Sieter Yary hanice Rasin, B.C.N., former moderator of Phe Roswithe Dramatio Club.

Ber. Urban Iagel, O.P., director general of The Blackfriare Guild.

Huch Sutton, momber of the Iit tle Theatre Compeny.

Euth Wileon, member of The Ittle Theatre Company.

Bagen C. Becloman, former president of the Loul sville Civic Theatre.

Iouls Lusk, Lion's 02ub prize winner.

Thelma Dolan, member of Board of Governors of The Little Theatre Company.

31ster Mary Ioul., 0.S.U., member of the executire ocmittee of The Catholio Theatre Conference.

Uary Jane unneield, former president of The Cathollc Theatre Guild Incorporated. 